DOI: $10.1515 /$ hssr -2015-0028

\title{
The Actor, the Pilgrim and the Fieldpath
}

Andrea Copeliovitch*

Fluminense Federal University (UFF), Brazil

\begin{abstract}
This article aims to cast a glance on some questions relevant for theatre, with an emphasis on the actor's point of view, not in order to investigate the acting practice but to develop a reflection. Theatre is a marginal art; an actor's action is a displacement action, out of the centre, searching, moving. Also, the actor is always a foreigner, a strange stranger. We follow these questions while going through the fieldpath, with direct reference to Martin Heidegger's text "Der Feldweg" (1949). As an actress, I try to understand it by walking my own path.
\end{abstract}

Key-words

Actor, Stranger, Silence, Tradition, Empty space.

\section{Siddhartha}

Hermann Hesse's work Siddhartha (1922) is a story about a pilgrim in search of knowledge. It is set in India when Buddha Sakyamuni got enlightened. In this work Hesse looks at Buddhism with Western eyes, yet not in a less wise manner. He divides the historical Buddha, Siddhartha Gautama, into two characters and makes us follow Siddhartha.

Siddhartha is the double and the shadow of Buddha, whom Hesse called Gautama. Siddhartha experiences all the excesses that Gautama was able to surpass. Siddhartha falls into the temptation of Mara, the snake - god of illusion. He goes through all aspects of human existence before attaining enlightenment. He is a traveller who undergoes experiences, in a

* Fluminense Federal University, 9 Miguel de Frias, 9-7th floor, 24.220-900 Icaraí-Niterói - RJ, Brasil; copeliovitch@hotmail.com 
displacement that is not only physical but also a displacement of his own self.

The actress would say:

I am an actress, a researcher, a Jewish and a wanderer. This story is interwoven with my research in theatre or, to put it better, in the tradition of Western theatre in which I was educated; a tradition of several masters and multiple paths, so discovering teachers and paths has included a continuous geographic displacement. Knowledge has been my pilgrimage.

This search is for understanding, which happens in this actress' body, on her obscure and tortuous paths. This search has never been about money, possessions or power. First and foremost, this actress tries to be free, free in her route, free not to belong to anyone or any place. She is a wanderer and might not care about being wrong for she knows that the only certainty is death.

Just like a comedian, Siddhartha experiences different characters and situations looking for his true self. He meets Gautama but he is not bent on following a doctrine; he knows that he needs to learn from his own experience and his own efforts.

Siddhartha goes to the river and it speaks to him; for the first time, Siddhartha hears the syllable ohm, a confluence of all the sounds in the universe. $\mathrm{Obm}$ is the understanding of this harmonic unit that Hindus, among others, believe to exist beyond the material world. The matter is Maya, illusion. To experience matter and become attached to it is the perpetuation of samsara, the cycle of existence and learning of human beings. It is through samsara that beings are able to evolve but the highest possible evolution would be to escape this circle. Buddha offers enlightenment and liberation from samsara to all those who will follow his teachings. Siddhartha does not accept this release; he needs to discover what and how he should transcend.

Siddhartha's path flows with the stream; it follows the river and anchors in a city where he becomes fascinated by Kamala. The search for his self becomes the search for the other; the motivation of Siddhartha's actions now is the conquest of Kamala's love and bed. 
To conquer Kamala - the courtesan, this pilgrim will learn how to earn money. At first, he is able to maintain some detachment from worldly issues: anger, disputes, attachments, beverage, meat; but little by little, he merges with this new role that he is playing and ceases to be the ascetic traveller to become a man of the world, a hostage of the every day.

Siddhartha's first attachment is games; the dart game appeals to him. Why games? Games are non-quotidian, provocative and dangerous but they have rules, and rules make them look secure. The material world has rules, mundane daily life is set in time and space, and it obeys laws: nature's laws, man's laws. Attachment makes it possible to play by the rules; if one has nothing to lose, how is it possible to make one obey rules unless one believes in them?

Of course Siddhartha would not live happily ever after with Kamala, so one day he would feel imprisoned and leave, he would again and again follow the river, he would meet his son, whose existence he even ignored. Kamala's son is the greatest love and attachment of his life. This child would not bear living with him, as he was already an old man. So his son, in his turn, would leave and make his own path.

The river is Siddhartha's teacher. In its fluidity he finds himself, the silence of his doubts. The river is a silent atmosphere and when he allows himself to listen to it, he listens to what needs to be listened to, to obm, the junction of all sounds, all voices of truth and mystery sung in perfect harmony.

In the river's water, Siddhartha sees the masks that he wore in his life; he sees himself, his encounters, all karma contained in these meetings. Karma, according to Buddhism, means the behaviours that we repeat, creating cyclical situations in our lives (or along various existences, depending on the tradition). Siddhartha realises that his son has left him just as he had abandoned his own father's House, never coming back, nor discussing it, nor saying good bye... and he understands that, at that time, he and his son are the same, different versions of a same story. He understands that those faces reflected in the River are the only possible truth, a truth that is not configured as a solid block, but explodes into pieces which come together and break apart in a continuous movement, appearing and being hidden in the depth and flow of waters. 
Siddhartha learns that there is no static truth, but that truth is movement, movement that hides and shows itself, veiling and revealing: the truth that the ancient Greeks called: Aletheia (Heidegger, 2008: 228).

Siddhartha gives us the perception that the self is not fixed, but it is also the movement of all these masks imprinted on the time line. This movement is Being, it is Dasein (Heidegger, 1989). Obm is permanence, it is To $B e$; it is a permanence that is also a verb, in motion; the harmony of the sounds that are and are not a conclusion. Siddhartha makes us comprehend the changing boundaries of being and truth. He also shows that he shall not remain and he is not the centre of the world.

Hesse shows us a possibility of not thinking of Man as the centre of the world, as the grand subject of action, making us reflect on such issues as Man, Being and Action. Heidegger proposes a new language to reflect on Being, a language that welcomes dualities, as art does (Heidegger, 1998). It can be very difficult to understand that language, to debate with philosophers of time and of logic.

Siddhartha's river is Heidegger's language. After his enlightenment, his friend Govinda asks him to teach him what he has learned. Siddhartha does not know how to teach. He knows that he has passed through all these paths and has arrived to the riverside several times, suffering, seeking... A few times the river spoke to him, but it was only in his old age, only after having lived the plenitude of the path, that he was he able speak, think and live in the language of the river.

\section{The field-path and the empty space}

$$
\begin{array}{r}
\text { On unity } \\
\text { Me and the other } \\
\text { An infinite, interminable movement } \\
\text { I am born, I die and I undo myself } \\
\text { by undoing, silence, peace } \\
\text { pursuing the soul, transfiguration } \\
\text { pilgrim, I am no longer the same. }
\end{array}
$$

Heidegger wrote a short text called The Fieldpath, Der Feldweg (1949). The field-path is simple and quiet. The passer-by should understand it in its simplicity and silence, in order to appreciate the path for its details. The fieldpath teaches us the tension between earth and the world: the earth's ancestry and the world's impermanence. The earth has always existed since 
the Big Bang and the creation of planets; the world has existed since humankind.

Between tradition and change, memory and oblivion, listening prevails in the field-path; otherwise this country road would be seen as a minor path in comparison to the straight, asphalted road where trails are not important, where we are not supposed to take detours, though it is through these trails that art advances. The poet, expelled from the polis, marches by the margins, by the riverside, instating spaces into the slits of the world.

We will try to understand the space instated by the poet as the empty space.

I can take any empty space and call it a bare stage. A man walks across this empty space whilst someone else is watching him, and this is all that is needed for an act of theatre to be engaged(Brook, 2008: 11).

Peter Brook wrote, described and inscribed the empty space in the theatrical scene. The empty space can be a concrete image: the stage stripped of scenarios, adornments, which Grotowski called "poor theatre" (Grotowski, 1968), an art that focuses on the figure of the actor. But the empty space goes beyond a scene without scenarios; the empty space is the understanding of the existence of this ephemeral art that is theatre. It is from this aphorism, from Brook's image/issue that we can begin to understand theatre; it is the slit where thought becomes alive and it also becomes theatrical scene.

The actor and the questions appear from this slit. The observer, intrigued, stops, engaged by this scene, trying to understand the act of crossing the empty stage. He might ask: where is he going? And why does this agent of action act that way? He crosses the empty stage and takes the observer with him, even though this observer does not move from his location in space. He can remain in his physical immobility as an observer and cross the empty space as well.

It is a difficult act to transport someone across the empty space. Surpassing this difficulty is what renders a stage theatrical: in the empty space, and starting from him.

Displacement constitutes the action of the Pilgrim, as well as the actor's: they are looking for something. 
The actor might say:

I cross the empty space; I try to attract a spectator's attention. I always want those who observe me to penetrate the empty space's magic.

\section{The pilgrim}

In 2003, I had a PhD internship in the Ethnoscenology Laboratory in Maison de Sciences de L'homme/Paris VIII. My research supervisor, Professor Jean-Marie Pradier, invited me to present my research to the other researchers, asking me the following questions: who are you? where are you? what do you do? what is the purpose of your research?

That same year, during holidays, I went on a pilgrimage to Santiago de Compostela. This pilgrimage became a sort of field research. It was not meant to be a field research, and it was not lived that way but afterwards, it made me reflect on what it means to be a pilgrim and on its relationship to the figure of the warrior actor, which was the subject of my doctoral research.

The warrior as described by Carlos Castaneda is a man in search of knowledge (Castaneda, 1968). His search and his impeccability distinguish him from common men. The actor, just like the warrior, must be impeccable in the execution of his action, independent of the result. In battle, the warrior is informed at all times about the danger of death. On stage, the actor must be informed of that same danger: the danger of failing to transpose the empty space and the danger of not being observed: to fail on stage is death.

In order to acquire impeccability a warrior must store energy, he must know that he should carry only the basics of utmost importance (like a pilgrim), because he knows that most of his luggage will not help him. On stage, unnecessary movements or words distract the observer and they might lead an actor to failure. The observer's attention is a result of his attention, so he brings himself constantly to the present time. Theatre happens here and now and an actor must know that living in the present is different from carpe diem.

I attended one of Jerzy Grotowski's conference at SESC Vila Nova in São Paulo, Brazil in 1996 and he said that on stage, emotions are like a wild tiger, very beautiful, but impossible to tame, and if we tame the tiger, it will 
cease to be wild. The actor as a warrior is a hunter and not a victim of tiger emotions. The pilgrim is also a kind of a warrior, a warrior who is a bit quixotic, a little bit out of this technological and chronological world.

Why should one walk hundreds of kilometres that could be covered in a few hours by car? What pushes all these people to leave behind their comfortable lives and suffer from calluses on their feet or from tendonitis? What makes them carry a ten-kilo backpack every day for 15 days, a month, or sometimes three months?

I tried to ask these questions to pilgrims on St. Jacob's Way. The answers varied. Some responded that they were doing it out of a search for personal development, some are motivated by religious reasons, others do it for tourism or sport; but these are not the reasons that set them in motion every morning; after the first day, the path itself becomes the reason.

The Mahabharata (Carrière, 1989) tells a story about the hero Ardjuna: during the war against the kaurava he could no longer find reasons to continue the battle. Krishna teaches him that "victory and defeat are the same", that what is important is action and that he should not reflect on the result of action.

An actor aims to this action of walking across the empty space. So, during my pilgrimage, while walking across the empty space, I tried to answer Professor Pradier's questions:

"Who are you?"

"I am Andrea, an actress, a researcher in life, a pilgrim, a warrior."

"Where are you from?"

"On the road? I always come from the previous city."

"Where are you going?"

"I always go to the next city."

"Why?"

"To get to Saint Jacob."

"When you get to St. Jacob, what are you going to do?"

"Me? I will go to Finisterra",

"And after that?"

... A pilgrim once told me: "The path does not end when you reach Saint Jacob, that is where it starts". 


\section{The stranger}

Georg Simmel, in his text The Stranger (1971) writes that in the Middle Ages, in Frankfurt, taxes were proportional to individual holdings; nevertheless, there was a common pre-established tax for all the Jews. During the Middle Ages, Jews did not possess lands. According to Judaism, Jews cannot kneel before anyone except God, so they could not take the faithfulness oath to the feudal lord, and thus be established in office. Also, the practice of usury was a sin for Christians. So how could a feudal lord entrust his land to a foreigner whose habits were so distinct from his own? How could he rely on this stranger?

Who is this stranger? What does it mean to be a stranger? The example of the Jews in the Middle Ages clearly shows what a stranger is. By not possessing lands, the Jews were not taxable. They were the unknown; one would not know what to say about them.

Fernando Pessoa, through his heteronymous persona/character Álvaro de Campos, in his poem titled "Lisbon Revisited," talks about the feeling of being a stranger in his own city. He looks at Lisbon with foreign eyes; the poem's title is originally in English, which already shows this expatriation.

\section{(...)}

You want me to be married, futile, predictable and taxable? You want me to be the opposite of this, the opposite of anything?

If I were someone else, I'd go along with you all.

But since I'm what I am, lay off?

Go to hell without me, or let me go there by myself?

Why do we have to go together?

Don't grab me by the arm!

I don't like my arm being grabbed.

I want to be alone,

I already told you that I can only be alone!

I'm sick of you wanting me to be sociable! ${ }^{2}$

(Pessoa, 1999)

The stranger is strange. The groups of people set in time and space search for a common sense, and the stranger is strange to what is common. 
To be stranger is a state; at any time a stranger could cease to be a foreigner. Perhaps a stranger is the one who wants to go to hell alone.

The pilgrim is a stranger by option. If man is not definable, if man can be the opposite of "no matter what", if we can understand him only as " $a$ rope stretched between the animal and the Overman - a rope over an abyss", as Nietzsche wrote in Thus Spoke Zarathoustra (Nietzsche, 1988:15), the stranger is a wrinkled rope, the ultimate expression of being indefinable: he is the one who passes by, who hits the road, and if he has not gone away yet, he might do it someday, because he does not have ties, he has no property.

One might think that nowadays foreigners can own property, they can have ties ... or maybe not. We go back to the word "indefinable" and also to the poem by Pessoa, who revisits Lisbon as another person (Álvaro de Campos) in another language, a stranger through his gaze but not through his roots, a stranger through his solitude and estrangement.

Jerzy Grotowski in his Hamlet Study (Studium o Hamlecie, 1964) presents Hamlet as a stranger, as a Jew and we see the estrangement in his relationship with Polish peasants. It is an ambiguous and ambivalent relationship: even though he is a stranger he also belongs to a tradition. It is not described as a relationship between torturer and victim, but as a relationship of identification and strangeness. In this relationship, the Jewish foreigner is also the poet expelled from the Polis. This play is an adaptation of the work of William Shakespeare and Stanislaw Wyspianski.

Since Exodus and the Diaspora, the Jew has historically been a stranger. Fernando Pessoa is still a foreigner while visiting a Lisbon where he does not belong. The actor is also a stranger, a juggler, a wanderer who used to go from one city to another, selling his art. The actress inside me could say "I am all of the above, by destination, by chance, by inheritance. I was born Jewish; I have a Polish grandfather, French roots, Russian and Romanian grandparents. All those grandparents spoke at least three languages each. I left the town where I was born at the age of eight; before being able to choose which path to follow, the path, the paths, had already chosen me... and at the age of eighteen, I left my father's house the same way Hesse's Siddhartha did." 


\title{
5. Displacement and tradition
}

Some poems accompany this actress like refrains in the course of her history and thought.

\author{
I Went \\ I brooked no bonds. \\ I threw off all restraint, \\ and went. \\ Toward enjoyments that were half \\ real - half ruminations of my brain, \\ into the illuminated night I went. \\ And of strong wines I drank boldly, as drink \\ they who seek after pleasure and are brave.
}

Constantinos Cavafy (2003)

She would say:

Leaving the father's house was not exactly a choice, but a destination, always my displacements were caused by events that have pushed me to leave a place for another. But the desire to leave has always been with me, my choice is freedom to be what I am facing the inexorable destination. This freedom allows me and forces me to follow trails. It is in silence and in solitude that I know the next aspect of my destination. I'm a pilgrim. For each destination, I am a stranger, and on each journey, I am a clandestine. I do not have an obligation to behave like citizens recognized by society, I am what I am and I do not know what I am. At each port, I find an adventure, then, the silence and the fieldpath.

The fieldpath, the marginal path, the path that is not the fastest way to get somewhere, by walking on it we are thrown into the silence of the trails. The fieldpath refers to and reverences the past as tradition, but this path is not fixed, it is still evolving. Its trails keep moving, leading the traveller to unknown places.

From the field cross it bends toward the forest. Onward, past its edge it greets a tall oak, under which a roughly hewn bench stands. Occasionally there lay on the bench some writing or another by the great thinkers, which a young awkwardness attempted to decipher. Whenever the riddles pressed upon each 
other and no way out was in sight, the field-path helped, for it quietly guided the foot on a turning path through the expanse of the barren land.

Time and again, thinking follows in the same writings, or goes by its own attempts on the trail where the field-path passes through the field. (Heidegger, 2015: 01).

On the first night of Pessa'h, Jewish Easter, Jews initiate the celebration of their exodus from Egypt, when they ceased to be slaves and became free men. On this night they eat Matza. In the race to escape, they forgot to ferment bread, so they could only eat Matra, bread without leaven. That night, they start reading the Haggadah, the book that retells the escape from Egypt and the forty years that Jews wandered in the desert.

During eight days the Jews celebrate Pessa'b and cannot eat fermented foods. For the Seder dinner, they eat bitter roots to recall the bitterness of slavery, and ten drops of wine are drained on a plate, to become blood, and each drop of blood becomes one of the ten plagues launched on the Pharaoh and on the Egyptians.

The meal takes us back in time; the wine of the feast becomes the sacrificial blood. The historical facts in the book become sacred and history ceases to be in the past; it happens during that night, making it different from all the other nights of the year.

The youngest child chants a ritual question: "why is this night different from all other nights of the year?" We assume they already know that this night is different, or perhaps the question itself is a ploy to show that that night is different, and the answer is the mythical way of presenting and representing the Jews' escape from Egypt as if it were happening that night, so that children and adults should know again and again that one day they were slaves, but now they are free men.

By repeating this journey from slavery to freedom, time and history cease to belong to a straight line. Time and history here belong to the context of the sacred and of the myth which is told, celebrated and presented. The dining room becomes a sacred space: Egypt, the desert, the Promised Land. The family members are: Moses, the treacherous Pharaoh, slave Jews and free Jews: actors and spectators, participants in a sacred time/ space. Sacred, mysterious and mutant... sacred space whose mystery the youngest son tries to uncover or to understand by repeating 
the verses of the song. Or maybe this mystery is evoked only in the echo of the question itself.

\section{Theatre and tradition}

Artaud, in his text "Le théâtre, avant tout, rituel et magique" (Artaud, 1995: 75, 76), explains how theatre comes from ritual and aims to get back to it. He presents the idea of an initial totality, its dismantling and subsequent search for unity. He believes that theatre comes originally from this dismantling; it comes from the ritual's decadence which, once it gets to its most decadent aspect, it will start covering the laborious way back, from theatre to ritual. Ritual here can be understood as the point of origin, that which is before and beyond the moment when we live and when everything has become linear, represented, rationalised. Ritual is what establishes the time and space evoked by the youngest child during Pessa'b.

Through myth we can understand the origin of the world and the origin of theatre as a communion with the forces of nature. Man originally belongs to the movement of cosmos and this movement is also chaos, danger and integrity.

This origin is neither the foundation, nor a moment in chronological time; it is the beginning and the end of existence, that which is beyond, which is unity, and it is obm.

In theatre, myth is presented and re-presented by the action of the chorus and by the action of the coryphée. This action happens in the théa tron, the space where one contemplates. The Greek root théa means to contemplate, which is different from seeing, watching (that would be órassis, orao). The suffix tron denotes the place where something happens, space (vacuum). People contemplate this action in the empty space meant for nonquotidian events.

This action is poiesis and it differs from all other actions. Every time it is repeated, it attempts to become different and unique, as if there had always been a young child to repeat the question, so that we all could be able to repeat and contemplate the meaning of the sacred event.

The child repeats the question, which repeats the meaning of the Pessa'b evening, leading us to understand that we do not live on clear ground and we do not ride on asphalt; rather, we travel on the fieldpath. The repetition of the myth is Man's ancestral understanding of the circular motion of the 
universe, the round earth, repeating day and night, seasons, cycles; a circle that can only be interrupted by chaos and mystery.

At a certain point during his navigation, Odysseus/Ulysses reached the abyss of the world. The actor at the centre of the scene (at the margin of the world) acts as Odysseus and walks on the paved earth re-presenting the sense of the circle and the abyss of the world. He listens to the river, wanders in the field-path and empties the space (stage) of its everyday logic (chronologic), making each night different from the other nights...

\section{References}

Artaud, A. (1999). Linguagem e vida. São Paulo: Perspectiva, 1995. Barba, E. Land of ashes and diamonds. My apprenticeship in Poland, followed by 26 letters from Jeray Grotowski to Eugenio Barba. Aberystwyth: Black Mountain Press,.

Brook, P. (2008). The Empty Space. London: Penguin.

Campos, A. (1997). Livro de Versos. Lisboa: Editorial Estampa.

Carrière, J.C. (1989). Le Mahâbhârata. Paris: Belfond.

Castaneda, C. (1982). Viagem a Ixtlan. Rio de Janeiro: Record.

Cavafy, C. P. (2003). Poems by C. P. Cavafy. Translated by J. C. Cavafy. Athens: Ikaros.

Grotowski, J. (1968). Towards a Poor Theatre. New York: Simon and Shuster.

Heidegger, M. (1962). Chemins qui ne mènent nulle part. Paris: Gallimard.

Heidegger, M. (1989) El Ser y el Tiempo. Buenos Aires: F. Cultura Economica.

Heidegger, M. (1949). Der Feldweg. Gesamtausgabe 013: Aus der Erfahrung des Denken.

Heidegger, M. (2008). Ensaios e Conferências. Petrópolis: Vozes.

Heidegger, M. "The Fieldpath." available online at https://seedzen.files. wordpress.com/2012/03/heidegger-the-fieldpath.pdf, accessed on 19 August 2015.

Heidegger, M. (1998). "Traditional language and technological language" (W. Gregory, Trans.). Journal of Pbilosophical Research 23. London: Routledge. 129145.

Hesse, H. Sidarta. Rio de Janeiro: Civilização Brasileira, 1968.

Nietzsche, F. (1988). Assim falou Zaratustra. São Paulo: Círculo do livro.

Pessoa, F. (1999). Fernando Pessoa and co.: selected poems. Translator Richard Zenith.

New York : Grove Press.

Platão. (1993). A República. Translator M. H. R. Pereira. Lisboa: Fundação Calouste Gulbenkian. 
Simmel, G. (1971). "The Stranger" in Georg Simmel on Individuality and Social Forms. edited by Levine, D. Chicago: The University of Chicago Press. 143-149.

${ }^{1}$ Finnisterra is the village where the ancient pagan path (that followed the sunset) ended.

${ }^{2}$ Translated by Richard Zenith. The original quotation of Campos' poem in Portuguese is:

"Queriam-me casado, fútil, quotidiano e tributável?

Queriam-me o contrário disto, o contrário de qualquer coisa?

Se eu fosse outra pessoa, fazia-lhes, a todos, a vontade.

Assim, como sou, tenham paciência!

Vão para o diabo sem mim,

Ou deixem-me ir sozinho para o diabo!

Para que havemos de ir juntos?

Não me peguem no braço!

Não gosto que me peguem no braço. Quero ser sozinho.

Já disse que sou sozinho!

Ah, que maçada quererem que eu seja da companhia! " (Campos, 1997)

\section{Biographical note}

Andrea Copeliovitch, an actress and theatre director, teaches Dance and Performance at the Fluminense Federal University, in Brazil. Her research interests include an examination of theatre as ritual, the boundaries between theatre and dance, acting as poiesis and the actor as a stranger, which she has developed at the Centre d'études sur l'Actual et le Quotidien, Paris V. She is part of the international academic community, having attended conferences in Greece, England, France and Portugal, with publications in Portuguese and English. She has contributed to innovation in the Brazilian dance and theatre, especially in the city of Natal, directing the group Gaya Dança Contemporânea. 